\title{
PENGGUNAAN LEMBAR KERJA BERBASIS PROBLEM BASED LEARNING UNTUK MENINGKATKAN KETERAMPILAN PROSES SAINS MAHASISWA
}

\author{
Riri Aisyah ${ }^{1}$, Fitri Nur Aisyah ${ }^{1}$, Yunita $^{2}$ \\ ${ }^{1}$ Program Studi Pendidikan Kimia, Fakultas Tarbiyah dan Keguruan, UIN Sunan Gunung \\ Djati Bandung, Jl. A.H. Nasution 105 Bandung 40614 Indonesia \\ ${ }^{2}$ Program Studi Tadris IPA Biologi, IAIN Syekh Nurjati Cirebon, Indonesia \\ E-mail: ririaisyah@ymail.com
}

\begin{abstract}
ABSTRAK
Tujuan penelitian ini untuk menganalisis kemampuan mahasiswa dalam menggunakan LKM berbasis PBL pada penentuan kadar asam palmitat bebas dalam minyak goring dan menganalisis keterampilan proses sains. Metode penelitian yang digunakan adalah penelitian kelas pada mahasiswa mata kuliah kimia bahan makanan sebanyak 38 orang. Data diperoleh dari jawaban mahasiswa dalam menyelesaikan setiap tahapan LKM yang diberikan, sedangkan keterampilan proses sains didapat dari jawaban siswa pada LKM yang disesuaikan dengan indikator ketrampilan proses sains. Kemampuan mahasiswa dalam menyelesaikan LKM diinterpretasikan sebagai berikut : fase "orientasi pada masalah" baik (70.3), fase"belajar mandiri' baik (76.0), fase"penyelidikan" baik sekali (94.3), fase"penyajian data" baik (72.7) dan fase"evaluasi hasil kerja" baik (72.4).Keterampilan proses sains mahasiswa secara keseluruhan diinterpretasikan baik dengan rata-rata 75.6, dengan perolehan nilaipada indikator mengamati 88.9, mengajukan pertanyaan 70.3, mengajukan hipotesis 70.8, menerapkan konsep 75.6, merancang percobaan 91,6, menyimpulkan 67.3 dan mengomunikasikan 73.1.
\end{abstract}

Kata kunci: keterampilan proses sains, LKM, problem based learning

\begin{abstract}
The purpose of this study was to describe the student activity, analyze the ability of students in completing each stage of the worksheet, and analyze the science process skills. The method used in this research was classroom research with subjects of 38 students taking chemical food ingredients course. The instrument used was a student observation sheet, worksheet and assessment rubrics. Based on data obtained research results showed that the observation of student activity is interpreted very well by obtaining the percentage of $94.9 \%$, in the phase of orienting problems $88.9 \%$, independent study $100.0 \%$, do investigation $100 \%$, presenting and developing data is $92.4 \%$, as well as analyze and evaluate the results of $93.3 \%$. The ability of students completing worksheet interpreted as follows: Phase 1 well (70.3), phase 2 well (76.0), phase 3 well (94.3), phase 4 well (72.7) and phase 5 well (72.4). Science process skills of students interpreted either with acquisition of the observed value with value of 88.9, ask questions70.3, propose hypotheses 70.8, applying concept 75.6, designing experiments 91.6, concludes 67.3 and communicating 73.1.
\end{abstract}

Keywords: science process skills, worksheet, problem based learning

DOI: http://dx.doi.org/10.15575/jta.v2i1.1368 


\section{PENDAHULUAN}

Salah satu strategi pembelajaran yang mandiri dan disarankan dari Kerangka Kualifikasi Nasional Indonesia (KKNI) adalah pembelajaran berbasis masalah atau problem based learning. Problem based learning adalah belajar dengan memanfaatkan masalah, kemudian mahasiswa harus melakukan pencarian informasi atau proses inquiry untuk dapat memecahkan masalah tersebut. Dari hasil studi pendahuluan selama menjadi asisten praktikum Kimia Organik II, kegiatan praktikum belum mengembangkan keterampilan proses sains pada beberapa indikator, mahasiswa hanya melaksanakan praktikum sesuai prosedur praktikum yang sudah baku dalam modul praktikum. Kegiatan praktikum membutuhkan Lembar Kerja Mahasiswa (LKM) dengan pendekatan masalah yang diharapkan dapat menuntun mahasiswa dalam merancang dan melakukan percobaan untuk memecahkan masalah serta menemukan konsep secara mandiri. Menurut penelitian sebelumnya menyatakan bahwa keterampilan proses sains siswa pada konsep larutan penyangga memperoleh kategori baik pada beberapa indikator keterampilan proses sains dengan pendekatanproblem based learning (Gustriana, 2012).

Peneliti tertarik untuk melakukan penelitian dengan rumusan masalah mengenai bagaimana aktivitas mahasiswa, kemampuan mahasiswa dalam menyelesaikan LKM berbasis Problem Based Learning dan keterampilan proses sains mahasiswa yangdikembangkan pada penentuan kadar asam palmitat bebas dalam minyak goreng dengan menggunakan LKM berbasis problem based learning. Adapun tujuan penelitian ini adalah untuk mendeskripsikan aktivitas mahasiswa, menganalisis kemampuan menyelesaikan LKM dan menganalisis keterampilan proses sains yang dikembangkan..

LKM berbasis problem based leraning merupakan alat bantu dalam pembelajaran yang melibatkan mahasiswa secara aktif menemukan dan menghubungkan konsep dengan bantuan fasilitator pada pelaksanaan praktikum. LKM praktikum yang mengikuti alur tahapan Problem Based Learning secara tidak langsung membangun keterampilan proses sains mahasiswa.Langkah utama pada pengajaran berdasarkan masalah menurut Ibrahim dan Nur dalam Al-Tabany (AlTabany, 2014) mengorientasikan mahasiswa pada masalah, mengorganisasikan mahasiswa untuk belajar, membimbing penyelidikan individual atau kelompok, mengembangkan dan menyajikan data, serta menganalisis dan mengevaluasi hasil kerja. Pembelajaran IPA seringkali memisahkan antara keterampilan teoritis dan praktis, meskipun seharusnya kedua komponen harus diterapkan bersamasama dalam praktek kehidupan nyata. Problem Based Learning menawarkan instruktur kerangka yang akan digunakan untuk membantu mahasiswa dalam belajar dan mengembangkan keterampilan teoritis dan praktis secara bersamaan (Boothalingam, 2009). Menurut penelitian sebelumnya, keterampilan proses sains siswa pada konsep larutan penyangga yang dikembangkan dengan model Problem Based Learning pada indikator menerapkan konsep memperoleh nilai rata-rata 71.3 dengan kategori baik, dan indikator mengklasifikasikan memperoleh nilai rata-rata 81.2 dengan kategori sangat baik (Gustriana, 2012).

Penentuan kadar asam palmitat bebas pada minyak goreng didasarkan pada prinsip penentuan keasaman pada lemak dengan metode titrasi asam basa. Salah satu metode titrasi asam-basa yang sering digunakan untuk menentukan konsentrasi suatu asam adalah metode alkalimetri.Metode alkalimetri merupakan metode reaksi penetralan asam dengan basa (Harjadi, 1986).

\section{METODE PENELITIAN}

Desain penelitian yang digunakan pada penelitian ini adalah penelitian kelas karena 
bertujuan untuk mengetahui keberhasilan mahasiswa setelah mengikuti pembelajaran, melacak kemajuan dan ketercapaian kemampuan peserta didik (Arikunto, 2010). Subjek penelitian ini adalah mahasiswa semester genap yang sedang mengikuti mata kuliah kimia bahan makanan yang terdiri dari 38 mahasiswa. Mahasiswa secara berkelompok melakukan praktikum penentuan kadar asam palmitat bebas dalam minyak goreng dengan menggunakan LKM berbasis Problem Based Learning yang diisi secara individual sebagai petunjuk untuk melakukan eksperimen. Dalam penelitian ini teknik pengambilan data dilakukan melalui lembar observasi proses pembelajaran, dan jawaban LKM.

Data yang diperoleh dari LKM merupakan data kemampuan mahasiswa dalam menyelesaikan setiap tahapan Problem Based Learning dalam LKM dan keterampilan proses sains mahasiswa pada saat pembelajaran. Pengolahan data diolah dengan tahapan berikut : memberi skor mentah terhadap setiap jawaban mahasiswa berdasarkan kriteria penilaian secara kualitatif dan mengubah skor mentah ke dalam bentuk nilai.

\section{HASIL DAN PEMBAHASAN}

Aktivitas mahasiswa dengan digunakannya LKM berbasis problem based learning secara keseluruhan diinterpretasikan sangat baik dengan persentase 93.3\% Rincian data observasi aktivitas mahasiswa diperlihatkan oleh Tabel 1.

\section{Tabel 1. Hasil Observasi Aktivitas Mahasiswa pada Setiap Tahapan Problem Based Learning}

\begin{tabular}{|l|l|}
\hline Tahapan & Nilai \\
\hline $\begin{array}{l}\text { Fase } 1: \text { Mengorientasi pada } \\
\text { masalah penentuan kadar asam } \\
\text { palmitat bebas }\end{array}$ & $88.9 \%$ \\
\hline
\end{tabular}

\begin{tabular}{|l|l|}
\hline $\begin{array}{l}\text { Fase 2 : Belajar Mandiri mengenai } \\
\text { konsep penentuan kadar asam } \\
\text { palmitat bebas }\end{array}$ & $100.0 \%$ \\
\hline $\begin{array}{l}\text { Fase 3 : Melakukan penyelidikan } \\
\text { dengan praktikum penentuan kadar } \\
\text { asam palmitat bebas }\end{array}$ & $100.0 \%$ \\
\hline $\begin{array}{l}\text { Fase } 4 \text { : Menyajikan dan } \\
\text { mengembangkan data pengamatan } \\
\text { praktikum penentuan kadar asam } \\
\text { palmitat bebas }\end{array}$ & $92.4 \%$ \\
\hline $\begin{array}{l}\text { Fase 5 : Menganalisis dan } \\
\text { mengevaluasi hasil praktikum } \\
\text { penentuan kadar asam palmitat } \\
\text { bebas }\end{array}$ & $93.3 \%$ \\
\hline Rata-rata Nilai & $94.9 \%$ \\
\hline
\end{tabular}

Berdasarkan komentar observer pada beberapa tahapan pembelajaran mahasiswa dapat bekerja secara mandiri. Hal ini sesuai dengan Siregar (Siregar, 2010) yang mendefinisikan bahwa Problem Based Learning merupakan pembelajaran yang berorientasi pada proses belajar siswa dan Barrows dalam Siregar (Siregar, 2010) juga menyebutkan bahwa dengan Problem Based Learning dapat meningkatkan kemajuan mahasiswa untuk mengarahkan diri sendiri.

Aktivitas mahasiswa dengan penggunaan LKM berbasis Problem Based Learning pada fase mengorientasi masalah diawali dengan kegiatan membaca wacana mengenai asam lemak bebas dalam minyak goreng dan mengamati sampel beberapa merek minyak goreng yang belum mengalami penggorengan dan telah mengalami penggorengan. Menurut pengamatan observer sebagian mahasiswa terfokus pada wacana LKM dan tidak terfokus pada stimulus untuk memperhatikan sampel miyak yang disajikan, sehingga hanya sebagian mahasiswa yang melakukan pengamatan langsung terhadap sampel yang disajikan.

Aktivitas mahasiswa pada fase belajar mandiridiperlihatkan dengan pengamatan mahasiswa pada indikator berhipotesis, menentukan tujuan dan menuliskan prinsip dari praktikum penentuan kadar asam palmitat bebas dalam minyak goreng yang akan dilakukan. Aktivitas pada fase ini teramati bahwa mahasiswa aktif dan 
menunjukkan kemandirian dalam mengerjakan LKM.

Aktivitas mahasiswa pada fase melakukan penyelidikan pada pengamatannya mahasiswa mampu mengembangkan wacana yang terdapat dalam LKM, sehingga mampu menentukan alat dan bahan yang diperlukan, membuat prosedur dan melaksanakan percobaan penentuan kadar asam palmitat bebas untuk setiap sampel minyak sebagai kegiatan dari fase ini.

Aktivitas mahasiswa pada fase menyajikan dan mengembangkan data, menunjukkan bahwa seluruh mahasiswa mampu melakukan pengumpulan data pengamatan dan pengolahan data secara mandiri. Aktivitas mahasiswa pada fase menganalisis dan mengevaluasi hasil kerja, observasi menunjukkan bahwa mahasiswa dapat melakukan komunikasi lisan yang cukup baik, menggunakan bahasa yang sesuai dengan kaidah dan lugas. Namun, secara konten yang disampaikan mahasiswa merupakan simpulan atau penyampaian hasil percobaan yang telah dilakukan. Mahasiswa mengomunikasikan kadar dari setiap sampel yang diuji tanpa membahas kegiatan yang telah dilakukan.

Hasil analisis kemampuan mahasiswa menyelesaikan LKM pada setiap tahapan problem based learning dikategorikan baik, dengan rincian data untuk tahapannya diperlihatkan pada Tabel 2.

Tabel 2. Hasil Analisis Kemampuan Mahasiswa Menyelesaikan LKM Berbasis Problem Based Learning

\begin{tabular}{|l|l|l|}
\hline Tahapan & Nilai & Interpretasi \\
\hline $\begin{array}{l}\text { Fase 1 : Mengorientasi } \\
\text { pada masalah }\end{array}$ & 70.3 & Baik \\
\hline Fase 2 : Belajar Mandiri & 76.0 & Baik \\
\hline $\begin{array}{l}\text { Fase3 : Melakukan } \\
\text { penyelidikan }\end{array}$ & 94.3 & Baik Sekali \\
\hline $\begin{array}{l}\text { Fase 4 : Menyajikan dan } \\
\text { mengembangkan data }\end{array}$ & 72.7 & Baik \\
\hline $\begin{array}{l}\text { Fase 5 : Menganalisis } \\
\text { dan mengevaluasi hasil }\end{array}$ & 72.4 & Baik \\
\hline
\end{tabular}

Fase mengorientasi masalah ditunjukkan dengan pertanyaan yang menuntut mahasiswa untuk merumuskan permasalahan berdasarkan wacana dan pengamatan terhadap sampel minyak. Rumusan masalah yang diajukan mahasiswa memiliki keanekaragaman, hal ini menunjukkan bahwa Problem Based Learning memberikan kebebasan pada mahasiswa untuk merumuskan masalah sesuai dengan apa yang terlintas dipikirannya, namun tugas pembimbing adalah mengarahkan mahasiswa untuk mengorientasikan mahasiswa pada masalah yang kontekstual (Rusman, 2013). Dalam hal ini kemampuan pembimbing merupakan salah satu hal penentu kesuksesan tahapan berlangsung.

Fase belajar mandiri diperlihatkan dengan pertanyaan yang menuntut mahasiswa untuk mengajukan hipotesis, tujuan praktikum dan prinsip praktikum. Sebagian banyak mahasiswa menuliskan tujuan percobaan sesuai dengan yang diharapkan, yaitu dapat menentukan kadar asam palmitat bebas dalam minyak yang telah mengalami dan belum mengalami penggorengan atau mengetahui pengaruh penggorengan terhadap kadar asam palmitat bebas, dan menentukan minyak yang aman digunakan. mahasiswa ada yang menuliskan hipotesis bukan sebagai jawaban sementara dari rumusan masalah yang diajukan, sehingga hipotesis yang diajukan menjadi tidak sesuai. contohnya merumuskan masalah mengenai dampak asam lemak bebas terhadap kesehatan padahal yang diharapkan adalah mahasiswa mengajukan hipotesis bahwa kadar asam palmitat bebas dapat ditentukan dengan konsep titrasi asam basa. Pada prinsip percobaan, seluruh mahasiswa memahami bahwa praktikum yang akan dilakukan pada dasarnya merupakan aplikasi dari titrasi asam basa. Dalam hal ini 
mahasiswa dapat menerapkan konsep dengan pengetahuan awal yang dimilikinya.

Fase melakukan penyelidikan ditampilkan dengan pertanyaan yang menuntut mahasiswa untuk menuliskan alat, bahan dan prosesdur penentuan kadar asam palmitat bebas. Hasil menunjukkan bahwa jawaban mahasiswa sesuai yang diharapkan yaitu menuliskan alat, bahan dan prosedur untuk pembuatan larutan dan pelaksanaan titrasi asam basa. Prosedur praktikum ini terdiri dari 3 langkah, yaitu : menyiapkan larutan baku, melakukan standarisasi larutan titran dan melakukan titrasi penentuan kadar asam palmitat bebas dalam minyak goreng. Alat dan bahan yang dituliskan mahasiswa sesuai dengan kebutuhan untuk melaksanakan praktikum, begitu juga prosedur yang dituliskan sesuai dengan yang diharapkan. Prosedur titrasi merupakan prosedur praktikum yang telah dipelajari pada mata kuliahanalitik II, sehingga pada dasarnya mahasiswa mampu menggunakan pengetahuan awal pada situasi baru yang ditemukan.

Fase mennyajikan dan mengembangkan data ditunjukkan dengan pertanyaan yang menuntuk mahasiswa untuk menuliskan data pengamatan dan reaksi yang terjadi. Fase menganalisis dan mengevaluasi hasil ditunjukkan dengan pertanyaan untuk menuliskan data hasil perhitungan kadar asam palmitat bebas tanpa memberi simpulan minyak mana yang layak untuk digunakan, begitu juga prosedur yang telah dilakukan. Pada aktivitas mengomunikasikan mahasiswa sudah mampu berbicara dengan lugas dengan mengomunikasikan laporan hasil percobaan dan kualitas dari berbagi minyak berdasarkan kadar asam palimitat bebas serta menginformasikan minyak yang dapat digunakan. Sesuai dengan Hamalik (Hamalik, 2005) bahwa dalam kegiatan mengomunikasikan mahasiswa harus mampu menyusun dan menyampaikan hasil dan laporan secara sistematis.

\section{Tabel 3. Keterampilan Proses Sains yangDikembangkan dengan LKM Berbasis Problem Based Learning}

\begin{tabular}{|l|l|l|l|}
\hline No & $\begin{array}{l}\text { Indikator } \\
\text { keterampilan } \\
\text { proses sains }\end{array}$ & $\begin{array}{l}\text { Nilai } \\
\text { rata- } \\
\text { rata }\end{array}$ & Interpretasi \\
\hline 1 & Mengamati & 88.9 & Baik Sekali \\
\hline 2 & $\begin{array}{l}\text { Mengajukan } \\
\text { pertanyaan }\end{array}$ & 70.3 & Baik \\
\hline 3 & $\begin{array}{l}\text { Mengajukan } \\
\text { Hipotesis }\end{array}$ & 70.8 & Baik \\
\hline 4 & $\begin{array}{l}\text { Menerapkan } \\
\text { konsep }\end{array}$ & 75.6 & Baik \\
\hline 5 & Menyimpulkan & 67.3 & Cukup Baik \\
\hline 6 & $\begin{array}{l}\text { Mengomunikas } \\
\text { ikan }\end{array}$ & 73.1 & Baik \\
\hline 7 & $\begin{array}{l}\text { Merancang } \\
\text { percobaan }\end{array}$ & 91.6 & Baik Sekali \\
\hline
\end{tabular}

Mahasiswa menunjukkan pengamatan yang menyeluruh seperti menuliskan perubahan yang terjadi untuk setiap prosedur praktikum yang dilakukan, menuliskan massa minyak dan volume dari setiap sampel yang digunakan beserta dengan penulisan yang tepat. Hal ini didukung juga dengan kinerja mahasiswa yang cenderung lebih mandiri dalam mengamati setiap perubahan yang terjadi pada kegiatan praktikum. Adanya kecenderungan mahasiswa untuk tidak menuliskan data pengamatan dengan lengkap bisa terjadi karena beberapa faktor, salah satunya adalah motivasi dalam diri. Menurut Dalyono (Tarsito, 2001) motivasi yang berasal dalam diri dapat mendorong kesadaran akan pentingnya sesuatu, sesuai dengan Conny, dkk. (Conny, 1992) mengatakan bahwa mengamati bukan hanya aktivitas melihat tetapi memilah mana yang penting dari yang kurang penting. Terdapat beberapa hal penting pada pengamatan yang tidak dituliskan oleh mahasiswa seperti tampilan minyak dari beberapa sampel minyak yang disajikan dan juga kelarutan minyak pada saat melalukan prosedur. Tampilan minyak dan kelarutan minyak dapat menghubungkan konteks dengan teori yang 
akan menjadi salah satu sumber pemahaman konsep.

Pada dasarnya, semua mahasiswa dapat mengajukan pertanyaan dengan baik, namun pertanyaan yang diajukan sebagai masalah yang akan dijadikan sebagai petunjuk untuk melakukan penyelidikan hanya diungkapkan oleh sebagian mahasiswa saja. Perbedaan dalam mengajukan pertanyaan diduga dari rasa keingintahuan dan adanya kemampuan menghubungkan masalah yang ada dalam kehidupan nyata dengan konsep kimia. Sesuai dengan pendapat Dalyono (Tarsito, 2001) bahwa rasa ingin tahu yang tinggi dapat meningkatkan kesungguhan seseorang dalam belajar.

Berdasarkan jawaban pertanyaan lembar kerja yang sesuai dengan keterampilan "berhipotesis" menunjukkan bahwa sebagian banyak mahasiswa mengajukan hipotesis yang sesuai dengan rumusan masalah yang diajukan serta memiliki kesesuaian pula dengan variabel eksperimen yang akan dilakukan seperti pengaruh penggorengan dan proses pembuatan minyak terhadap kadar asam palmitat bebas. Sesuai dengan Rustaman (Rustaman, 2000) yang mengatakan bahwa berhipotesis artinya dapat merumuskan dugaan atau jawaban sementara, atau menguji pernyataan yang ada dan mengandung hubungan dua variabel atau lebih, biasanya mengandung cara kerja untuk menguji atau membuktikan. Seluruh mahasiswa pada dasarnya dapat mengajukan pertanyaan, namun pertanyaan yang diajukan mahasiswa memiliki keanekaragaman, ada yang bertanya mengenai dampak asam lemak bebas terhadap kesehatan, penyebab timbulnya asam palmitat bebas dan banyak mahasiswa yang cenderung bertanya berapa kadar asam palmitat bebas didalam sampel yang disajikan.
Berdasarkan jawaban mahasiswa pada indikator yang sesuai dengan keterampilan "menerapkan konsep", menunjukkan mahasiswa melakukan analisis data melalui perhitungan penentuan kadar asam palmitat bebas dengan sangat baik. Mahasiswa memberikan rumusan masalah yang cukup tepat, sehingga tujuan percobaan yang diajukan memiliki kesesuaian dengan percobaan yang hendak dilakukan. Kekeliruan berdasarkan penulisan prinsip dan reaksi percobaan yang kurang tepat seperti adanya penulisan prinsip yang hanya menuliskan konsep dasar titrasi asam basa tanpa menyebutkan perlakuan khusus (pelarutan dalam alkohol) terhadap sampel minyak yang merupakan senyawa organik tak larut dalam air dan penulisan reaksi yang tidak menuliskan fasa dan struktur trigliserida atau asam lemak yang kurang tepat. Secara keseluruhan mahasiswa sudah baik dalam menerapkan pengetahuan awal yang dimiliki pada kondisi yang baru atau permasalahan yang dihadapi. Hal ini didukung oleh Farida (Farida, 2014) bahwa kegiatan menerapkan meliputi: menggunakan informasi, menarik kesimpulan, menghitung, menentukan variabel, dan menghubungkan konsep.

Keterampilan "merancang percobaan" ditinjau dari kegiatan mahasiswa menuliskan serta memilih alat, bahan dan prosedur secara mandiri, tanpa dibimbing oleh peneliti. Berdasarkan jawaban pertanyaan LKM yang sesuai dengan keterampilan "merancang percobaan" menunjukkan bahwa seluruh mahasiswa sudah baik dalam merancang percobaan yang dilihat dari penentuan alat dan bahan serta penulisan prosedur yang tepat. Ditinjau dari aktivitas mahasiswa, menunjukkan kemandirian dan rasa percaya diri mahasiswa dalam menentukan alat bahan dan melakukan praktikum. 
Dilihat dari jawaban LKM pada keterampilan "menyimpulkan" menunjukkan bahwa sebagian mahasiswa tidak dapat menghubungkan kesimpulan yang dibuat dengan rumusan masalah yang diajukan, seperti mengajukan pertanyaan mengenai bagaimana cara penentuan kadar asam palmitat bebas namun membuat kesimpulan mengenai kadar untuk masing-masing sampel minyak. Hal ini dapat terjadi karena beberapa faktor, salah satunya dapat dilihat dari kurang terfokusnya mahasiswa yang bisa saja disebabkan oleh keterbatasan waktu pembelajaran, karena jika ditinjau kegiatan menyimpulkan merupakan kegiatan akhir pembelajaran.

Keterampilan "mengomunikasikan" dilihat berdasarkan kesimpulan yang dibuat oleh mahasiswa dan laporan yang menunjukkan keterampilan mengomunikasikan secara tulisan. Hal ini dapat dilihat karena kelompok prestasi tinggi membuat kesimpulan yang berkesesuaian dengan rumusan masalah yang diajukan dan diharapkan yaitu membuat kesimpulan mengenai proses penentuan kadar asam palmitat bebas, pengaruh penggorengan terhadap kadar asam palmitat bebas dan menunjukkan minyak goreng yang layak digunakan berdasarkan kadarnya, sehingga konten yang dikomunikasikan lebih sistematis dan bermakna.Kemudian didukung dengan nilai laporan yang menunjukkan keterampilan mengomunikasikan secara tulisan diinterpretasikan baik sekali.

\section{Berdasarkan observasi kegiatan} mengomunikasikan menunjukkan bahwa mahasiswa sudah mampu mengomunikasikan dengan bahasa yang lugas dan suara ]yang cukup lantang sehingga mahasiswa lain dapat memahami apa yang disampaikan. Sehingga keterampilan mengomunikasikan ini dilihat dari komunikasi lisan dan tulisan, sesuai dengan pendapat Conny, dkk. (Conny,
1992)
mengatakan
bahwa
untuk menyampaikan hasil penemuan dapat dengan cara lisan maupun tulisan.

Peneliti melihat pelaksanaan praktikum lebih terarah karena mahasiswa dapat bekerja secara sistematis dan mandiri sesuai panduan LKM berbasis problem based learning. Keterampilan proses sains yang dikembangkan oleh LKM berbasis problem based learning ini pada dasarnya menunjukkan perkembangan yang baik. Penggunaan LKM berbasis problem based learning ini memberikan banyak kesempatan bagi mahasiswa untuk mengembangkan dirinya, selain keaktifan dalam pembelajaran serta kemandirian yang dibangun selama proses pembelajaran, LKM ini juga membantu mahasiswa untuk mentransfer pengetahuan mereka untuk memahami masalah dalam kehidupan nyata dengan proses ilmiah.

\section{KESIMPULAN}

Observasi aktivitas mahasiswa pada penentuan kadar asam palmitat bebas pada minyak goreng dengan menggunakan LKM berbasis Problem Based Learning secara keseluruhan diinterpretasikan baik. Pada kegiatan inti memperoleh persentase $94.9 \%$, dengan persentasi pada fase 1 mengorientasi masalah $88.9 \%$, fase 2 belajar mandiri $100.0 \%$, fase 3 melakukan penyelidikan $100.0 \%$, fase 4 menyajikan dan mengembangkan data $92.4 \%$ serta fase menganalisis dan mengevaluasi hasil 93.3\%. Kemampuan mahasiswa menyelesaikan LKM dalam setiap tahapan problem based learning pada penentuan kadar asam palmitat bebas pada minyak goreng dinyatakan sebagai berikut : fase 1 mengorientasi masalah interpretasi baik (70.3), fase 2 belajar mandiri interpretasi baik (76.0), fase 3 melakukan penyelidikkan interpretasi baik sekali (94.3), fase 4 menyajikan dan mengembangkan data interpretasi baik (72.7) dan fase 5 menganalisis dan mengevaluasi hasil kerja interpretasi baik (72.4). 
Keterampilan proses sains mahasiswa yang dikembangkan melalui penggunaan LKM berbasis problem based learning pada penentuan kadar asam palmitat bebas pada minyak goreng secara keseluruhan diinterpretasikan baik dengan rata-rata 75.6. Keterampilan proses sains pada mengamati memperoleh nilai rata-rata 88.9, mengajukan pertanyaan 70.3, berhipotesis 70.8, menerapkan konsep 75.6, merancang percobaan 91.6, menyimpulkan 67.3 dan mengomunikasikan 73.1.

\section{DAFTAR PUSTAKA}

Al-Tabany, T. (2014). Mendesain Model Pembelajaran Inovatif, Progresif, dan Kontekstual.Jakarta : Prenada Media Group.

Arikunto, S. (2010). Prosedur penelitian : Suatu Pendekatan Praktik. (Edisi Revisi). Jakarta: Rineka Cipta.

Boothalingam, S. (2009). Bridging Classroom and Lab Teaching in Audiology Using Problem Based Learning. Teaching Innovation Projects. 4, 113.

Conny, S. dkk. (1992). Pendekatan Keterampilan Proses. Jakarta : Gramedia Widia Sarana.

Farida, I., A. Y. (2014). Evaluasi Pembelajaran (Penilaian Proses dan Hasil Belajar IPA). Bandung: UIN Sunan Gunung Djati.

Gustriana, A. (2012). Penerapan model Problem Based Learning (promblem Based Learning) untuk Mengembangkan Keterampilan Proses Sains pada Konsep Larutan Penyangga. Skripsi, Fakultas Tarbiyah dan Keguruan : UIN SGD Bandung
Hamalik, O. (2005). Metoda Belajar KesulitanKesulitan Belajar. Bandung.

Harjadi, W. (1986). Ilmu Kimia Analitik Dasar. Jakarta : Gramedia.

Rusman. (2013). Model-model pembelajaran. Depok : Rajagrafindo Persada Conny, S. dkk. (1992). Pendekatan Keterampilan Proses. Jakarta : Gramedia Widia Sarana.

Rustaman, N. Y. (2000). Asesmen Pendidikan IPA. Bandung : UPI (Tidak diterbitkan).

Siregar, E. dan Hartini N. (2010). Teori Belajar dan Pembelajaran. Bogor : Ghalia Indonesia.

Tarsito Dalyono, M. (2001). Psikologi Pendidikan. Jakarta : Rineka Cipta. 